\title{
Strategies to Improve the Attractiveness of Sam Poo Kong Temple As Cultural Tourism Site of Semarang City, Central Java, Indonesia
}

\author{
Hertiana Ikasari \\ Study Program of Management, Faculty of Economics and Business, Dian Nuswantoro University, Semarang, Indonesia
}

\begin{abstract}
Culture plays a significant role in tourism. Indonesian tourism sets its regional cultures as one of its products' mainstays. The development of cultural tourism is one of the focuses of national tourism policy. Sam Poo Kong Temple is one of popular cultural tourism destinations in Semarang city. Besides the many benefits of the existence of Sam Poo Kong temple, there are also some problems with the presence of some tourist complaints. These complaints indicate that there is tourists' dissatisfaction with Sam Poo Kong temple. When tourists' satisfaction is not highly concerned, it will reduce the attractiveness of Sam Poo Kong Temple. This study aims to analyze the strategy to improve the attractiveness of Sam Poo Kong Temple as a cultural tourism object in Semarang city. The respondents in this study are domestic tourists. The data will be collected by using a questionnaire. This research was analyzed using ImportancePerformance Analysis (IPA). The results obtained show that the first performance priority to be improved is information attributes about the events held in Sam Poo Kong Temple through printed, electronic and social media and employee service quality attributes. This study suggested that, first, it needs to conduct various promotion forms of Sam Poo Kong Temple to improve the performance of attributes whose high priority. One of the easiest and the most inexpensive promotions is through social media. Second, it is necessary to improve the quality of human resources through both formal and informal training and HR development.
\end{abstract}

Keywords: Cultural tourism strategy, importance-performance analysis, Sam Poo Kong Temple, tourism attractiveness, tourist satisfaction.

\section{INTRODUCTION}

Tourism is an inseparable part of national development in Indonesia which is built on the uniqueness and distinctive of natural culture as well as relations among Indonesian people. The tourism sector has been one of the major foreign exchange earners and has become a commodity which the government relies on to be the main pillar of national economic development in Indonesia. Tourism development is carried out sustainably as an integral part of national development. In addition, Indonesia has a comparative advantage in the development of Indonesian tourism. The comparative advantage of tourism in Indonesia is the existence of religious norms and cultural values in every aspect of life [1].

Indonesia, a country that possesses considerably high tourism potential, needs to take an important part in tourism market share at the global level. In 2014, Indonesia's tourism sector's contribution to GDP on a macroeconomic basis was 9\% (IDR 946.09 trillion). Also, the tourism sector has contributed

Correspondence address:

Hertiana Ikasari

Email : hertiana.ikasari@dsn.dinus.ac.id

Address : Management Study Program, Dian Nuswantoro University, Semarang
IDR 140 trillion foreign exchange and 11 million employment opportunities. On a microeconomic basis, Indonesia's tourism competitiveness index is 70 (it is still inferior when compared to Singapore, Malaysia, and Thailand). The number of tourist arrivals was 9 million foreign tourists and 250 million domestic tourist trips. The contribution of the Indonesian tourism sector to world tourism is $0.8 \%, 3 \%$ contribution to the Asia Pacific region, and the contribution to ASEAN tourism is $9 \%$ [2].

The development of the national tourism sector has been regulated in Law No. 10 year 2009 about Tourism. The development of the tourism sector needs to be conducted in an integrated way with other related sectors and with such stakeholders as central government, regional governments, enterprises, and the community [3].

Cultural tourism development has become one of the focuses in national tourism policy. Cultural tourism is a type of tourism that resulted from the attractiveness of art and culture in an area or a place. At the first consideration, Law No. 10 year 2009 emphasizes that culture is one of the national tourism development resources. In another sentence, this can be interpreted as an acknowledgment and an affirmation that national culture diversity is significantly strategic 
as the basis for tourism development. This affirmation has broad meaning. First, culture in its intangible and tangible forms needs new meaning in terms of utilization to be tourist attraction. The uniqueness, authenticity and high diversity in the elements of Indonesian culture make it as an attractiveness which is not merely culturally valuable but it also has humanitarian value in economy. Second, culture as national wealth needs to be preserved for future generations and as national identity as well as and characteristics in international relations [4].

Cultural heritage can be explored to be tourism attraction since these assets display the uniqueness of the place or location which provides different experience for visitors and creates an attractive image of tradition, ethnic background, and destination landscape. The uniqueness of the object visited is highly valuable as it combines the value of scarcity, specificity, and pleasure. The opportunities for its development and exploration are even greater if it is supported by open accessibility in the market and added by other competitive excellences. These excellences can be in the form of heterogeneity of cultural tourism attraction. Diverse attractiveness which are related to others, e.g. in the form of museums, zoos, artifacts, heritage, scheduled performing arts and so on, can be categorized as elements of its excellence [4].

Indonesian tourism places regional cultures as one of the mainstays of its products. This is related to the diverse cultural potentials in each region. Cultural diversity is considered as one of the basic capitals to not only show Indonesian wealth as a multicultural country but also strengthen the image of Indonesia as a country, which is feasible as an international tourism destination [4].

In the context of cultural tourism development, it seems that there is an abundant potential of culture in various regions, which needs to be packaged in a proper way to provide greater benefits both economically and culturally in the form of strengthening national pride and identity. However, the potential of regional culture is still not optimally explored that it can improve tourism attractiveness. A quite prominent problem arising is the fact that cultural tourism management is mostly not optimal yet, and it always requires more creative innovation [4].

Semarang is an ideal city as a gateway to other cities in Central Java. Hence, Semarang is popularly known as a Transit City rather than a Tourist City. Semarang, on the contrary, has so many unique things to enjoy and tourism objects to visit [5]. There were 41 attractions in Semarang city in 2017. These tourism objects were in the form of natural tourism, cultural tourism, and artificial tourism.

Sam Poo Kong Temple is one of the popular cultural tourism destinations in Semarang city, Central Java province, Indonesia. Sam Poo Kong Temple was formerly the first landing and stop of a Muslim Chinese admiral named Cheng Ho. Then Sam Poo Kong temple is now used as a worship place of Tridharma adherents (Taoism, Buddhism, and Confucianism).

The existence of Sam Poo Kong Temple brings several benefits, for instance besides functioning as cultural preservation, place of religious practice, tourism objects, as well as being used by local residents to meet their economic needs. For the regional (city) government of Semarang City, Sam Poo Kong is one of the regional revenue sources (PAD) from the tourism sector. The enactment of Law no. 32 the Year 2004 gives greater authority to the Regional city Government to manage its region has led to the implications for the increased responsibilities and demands to explore and develop all the potential resources owned to sustain the development progress in the region, including tourism sector.

There are several problems found in Sam Poo Kong Temple as a tourism object in addition to its benefits. The results of the conducted pre-survey showed some complaints from Sam Poo Kong Temple visitors. The complaints include employees who are not friendly, visitors cannot enter certain places in Sam Poo Kong Temple, new buildings in the temple reduce the originality of the temple relic, the absence of pamphlets about Sam Poo Kong, lack of cleanliness, and many more. Furthermore, the results of the survey indicate that some tourists were dissatisfied with Sam Poo Kong Temple.

Tourists' satisfaction is one of the important factors that should be concerned by the manager of the tourism object since the tourism object will not be able to survive without tourists. In general, satisfaction is one's feeling of pleasure or disappointment arising because of comparing the performance of perceived products (or results) against their expectations. When the performance fails to meet the expectations, the customers will be dissatisfied. In contrast, when the performance meets the expectations, the customers will be satisfied or pleasant [6]. In the 
tourism context, the characteristics of tourists who are satisfied include: tourists will come to the tourism object again and will recommend the object to other people.

On the other hand, when tourists' satisfaction is not highly concerned, it will eventually reduce the attractiveness of Sam Poo Kong Temple, and it is feared that this will result in a decrease in the number of tourists coming to the temple. It did not only reduce the income of Sam Poo Kong Temple. It also reduced the income sources of the surrounding community.

The tourist attraction is an inter-related formation and facilities, which attract tourists to come. The attraction of a tourism object is based on the existence of the following criteria: (1) resources that may cause a feeling of pleasure, (2) beautiful and comfortable, (3) possess high accessibility to be visited, (4) special features or specifications which are rare, (5) supporting facilities and infrastructure to serve tourists who come there, and (6) a high attraction as it has a special values in the form of art attractions, traditional ceremonies, noble values contained in an object of human art work in the past [7]. By increasing the attractiveness of a tourist attraction, tourist satisfaction will increase simultaneously.

Several studies related to improve tourism attractiveness have been conducted [8-15], and this study will focus on strategies to increase the attractiveness of cultural tourism. Based on the aforementioned background, the purpose of this study is to analyze the strategy to increase the attractiveness of Sam Poo Kong as a cultural tourism attraction.

\section{MATERIAL AND METHOD Data Collection}

This research was conducted at Sam Poo Kong Temple. There were 100 respondents in this study. The criteria used to choose the respondents were the respondents must be domestic tourists and at least 18 years of age. The selection of domestic tourists was due to the fact that most visitors of Sam Poo Kong were domestic tourists.

The data used in this study consisted of primary and secondary data. Primary data collection was carried out by using a questionnaire consisting of two parts, the questionnaire of expectations (importance) and the questionnaire of domestic tourist perception on the performance (performance) of Sam Poo Kong tourism object.
There were 23 tourist attributes asked to the respondents including: security, parking space availability, availability of information and service centers in Sam Poo Kong Temple area, cleanliness in Sam Poo Kong Temple, cleanliness in the area around Sam Poo Kong Temple, toilet cleanliness, transportation facility, availability of restaurants around Sam Poo Kong Temple, access to reach the location, availability of lodging accommodation near Sam Poo Kong Temple, affordable entrance tickets, availability of complete unique souvenirs of Semarang and Sam Poo Kong, availability of special traditional food of Semarang Sam Poo Kong temple, art performance events related to local wisdom and religious ceremonies, the beauty of Sam Poo Kong Temple, quality of employee services, convenience, availability of information about activities in Sam Poo Kong Temple through printed, electronic and social media, information about Sam Poo Kong Temple via website, tour guides reliability, availability of places to rest inside Sam Poo Kong Temple area, ATM availability, availability of snacks and beverage stores around Sam Poo Kong. Furthermore, secondary data collection was obtained indirectly through intermediary media (obtained and recorded by other parties), including data from the manager of Sam Poo Kong tourism object. The secondary data in this study include the profile of Sam Poo Kong tourism objects.

\section{Data Analysis}

This study used Importance-Performance Analysis (IPA) analysis tool developed by Martilla and James [16] as a tool to facilitate management decisions. IPA has been developed and widely used for various studies, especially those related to performance improvement [17]. IPA combines measures of importance and performance attributes of a particular product in a two-dimensional matrix resulting in four quadrants. The first step for quadrant analysis is to calculate the average of importance and performance values for each attribute using the following formula:

$$
\begin{aligned}
& \overline{X_{i}}=\frac{\sum_{i=1}^{k} X_{i}}{n} \\
& \bar{Y}_{i}=\frac{\sum_{i=1}^{k} Y_{i}}{n}
\end{aligned}
$$


Where:

$\overline{X_{i}}=$ weight of average performance rating level of $\mathrm{i}$-th attribute

$\bar{Y}_{i}=$ weight of average performance rating level of $\mathrm{i}$-th attribute

$\mathrm{n} \quad=$ Number of respondents

The next step is to calculate the average of importance and performance level for the entire attributes using this formula:

$$
\begin{aligned}
& \overline{\overline{X_{i}}}=\frac{\sum_{i=1}^{k} \overline{X_{i}}}{n} \\
& \overline{\overline{Y_{i}}}=\frac{\sum_{i=1}^{k} \overline{Y_{i}}}{n}
\end{aligned}
$$

Where

$$
\begin{array}{ll}
\overline{\overline{X_{i}}} & =\text { average value of performance attribute } \\
\overline{\bar{Y}} & =\text { average value of importance attribute } \\
\mathrm{n} & =\text { number of attributes }
\end{array}
$$

After obtaining the weights of performance and importance attributes as well as the average value of performance and importance attributes, the values are plotted in Cartesian diagram as shown in Figure 1 [18].

\begin{tabular}{|c|c|c|}
\cline { 2 - 3 } IMPORTANCE & $\begin{array}{c}\text { Quadrant I } \\
\text { (Main } \\
\text { Priority) }\end{array}$ & $\begin{array}{c}\text { Quadrant II } \\
\text { (Maintain the good } \\
\text { performance) }\end{array}$ \\
\cline { 2 - 3 } Low & $\begin{array}{c}\text { Quadrant III } \\
\text { (Low } \\
\text { Priority) }\end{array}$ & $\begin{array}{c}\text { Quadrant IV } \\
\text { (Over performance) }\end{array}$ \\
& \multicolumn{2}{c}{ Low High } \\
\hline \multicolumn{2}{c}{ PERFORMANCE (X) }
\end{tabular}

Figure 1. Importance-Performance analysis quadrant

Quadrant $I$ is called the main priority (high importance and low performance). Furthermore, quadrant I show that service or product attributes are crucial according to consumers. However, the management is not yet able to implement as desired by consumers. Thus the consumers feel disappointed and dissatisfied. Therefore, the management is obliged to allocate adequate resources to improve the performance of those factors. The factors located in this quadrant are priorities to be improved.
Quadrant II is called maintaining performance (high importance and high performance). Quadrant II shows that service or product attributes, which considered to be important for consumers, have been well implemented by the management, and consumers feel satisfied. The factors in this quadrant are the factors whose performance should be maintained.

Quadrant III is called low priority (low importance and low performance). Quadrant III shows attributes that are considered less important by consumers, so the management should not prioritize or pay too much attention to these factors.

Quadrant IV is called over performance or excessive (low importance and high performance). Quadrant IV shows service attributes that are considered less important but have been carried out very satisfactorily by the management. It is considered excessive or overperformance.

\section{RESULT AND DISCUSSION Description Of Sam Poo Kong Temple}

Sam Poo Kong Temple is the oldest Chinese temple in Semarang. This temple has a 3.2 ha total area and is located in the southwestern of Semarang City. Like most temples in Indonesia, the building of Sam Poo Kong Temple is dominated by red color. Moreover, the building of Sam Poo Kong Temple adapted acculturation because the architect came from Mainland China.

Sam Poo Kong Temple is a complex of Tri Dharma worships (Kong $\mathrm{Hu} \mathrm{Cu}$, Tao, and Buddha). This temple was built on the basis of respect to Admiral Cheng Ho. The interesting thing is it has been discovered that Admiral Cheng Ho was a Muslim who also had an Arabic name, Haji Mahmud Shams. He was a sailor and explorer from China who was well known and explored the world in $1405-1433$.

Admiral Cheng $\mathrm{Ho}$ at that time was sailing through the Java sea. On his voyage, many of his crew members were ill, thus Admiral Cheng Ho decided to search for land. Finally, Admiral Cheng Ho sailed along the city mostly crossed by rivers, i.e. now Semarang City. Then he came to a cave surrounded by rock hills which are currently known as the Simongan region. Admiral Cheng Ho at last settled there.

The journey taken by Admiral Cheng Ho turned out to produce a Navigation Map of Cheng Ho. This navigation Map of Cheng Ho was 
able to change the world navigation map until the $15^{\text {th }}$ century.

There are several statues inside the complex of Sam Poo Kong Temple. One of them is the statue of Admiral Cheng Ho, that coated in gold. There is also an altar and the tombs of Admiral Cheng Ho's confidants. Due to the existence of the tomb, there are visitors come to make a pilgrimage to the tombs. There is also another place of pilgrimage, which is still in the complex of Sam Poo Kong Temple, i.e. Kyai Jangkar. Kyai Jangkar is the original anchor ship of Admiral Cheng Ho (Jangkar is a local term for anchor). In addition to Kyai Jangkar, there is also Dewa Bumi Temple (Dewa Bumi is a local term for Earth God), a place for religious practice or worship for the adherents of Kong $\mathrm{Hu} \mathrm{Cu}$ and Taoism. Since there is an Earth God Temple, the worshipers could express their gratitude and thankfulness to the Earth God. There is also Juru Mudi Temple (Juru Mudi is a local term for helmsman) and Sam Poo Tay Djien Temple, the largest temple in the complex of Sam Poo Kong.

Besides being a place for pilgrimage practice, there are also visitors who do Ciam Si rituals aiming to see a fortune in the future. This Ciam Si ritual is done by burning Chinese incense sticks inside Batu Cave, then they throw two wooden panels in front of the altar, if one panel is open and the other is closed, the visitor will get a fortune [19].

\section{Profile of Respondents}

In this section, a general overview of respondents will be presented by considering the characteristics of gender, age, latest education, occupation, and income, as shown in table 1. Based on the gender category, it can be seen in Table 1 that there is no significant difference between the number of males (51\%) and female (49\%) respondents. The majority of respondents' age is between 29 - 39 years old (36\%). Also, most respondents, $41 \%$, hold a bachelor's degree in education.

Meanwhile, most Sam Poo Kong Temple tourists' occupation is private employees (25\%). While the average respondents' income is mostly in the range of IDR. 2,500,000-5,000,000, which covers $43 \%$. This figure shows that most Sam Poo Kong Temple tourists are middle-class people.

\section{Importance-Performance Analysis Results}

Based on the Importance-Performance analysis (IPA) conducted, it can be concluded the attributes contained in quadrants I, II, III, and IV and the implications of the results as seen in Table 2. Based on table 2, these tourism attributes were grouped in each quadrant as the Figure 2.

Table 1. Profile of Respondents

\begin{tabular}{|c|c|c|c|}
\hline Characteristics & Description & Frequency (People) & Percentage \\
\hline \multirow[t]{2}{*}{ Gender } & - Male & 51 & $51 \%$ \\
\hline & - Female & 49 & $49 \%$ \\
\hline \multirow[t]{4}{*}{ Age } & - $18-28$ years old & 31 & $31 \%$ \\
\hline & - $29-39$ years old & 36 & $36 \%$ \\
\hline & - $40-50$ years old & 25 & $25 \%$ \\
\hline & - More than 50 years old & 8 & $8 \%$ \\
\hline \multirow[t]{7}{*}{ Latest Education } & - Elementary school & - & - \\
\hline & - Junior High School & - & - \\
\hline & - Senior High School & 20 & $20 \%$ \\
\hline & - Diploma & 28 & $28 \%$ \\
\hline & - Undergraduate/Bachelor & 41 & $41 \%$ \\
\hline & - Master & 9 & $9 \%$ \\
\hline & - Doctor/PhD & 2 & $2 \%$ \\
\hline \multirow[t]{6}{*}{ Occupation } & - Students/university students & 20 & $20 \%$ \\
\hline & - Housewives & 10 & $10 \%$ \\
\hline & - Entrepreneurs & 15 & $15 \%$ \\
\hline & - Civil employees & 22 & $22 \%$ \\
\hline & - Private employees & 25 & $25 \%$ \\
\hline & - Others & 8 & $8 \%$ \\
\hline \multirow[t]{4}{*}{ Income } & - < IDR. 500.000,- & 16 & $16 \%$ \\
\hline & - IDR. 500.000,--2.500.000,- & 17 & $17 \%$ \\
\hline & - > IDR. 2.500.000,-- 5.000.000,- & 43 & $43 \%$ \\
\hline & - > IDR. 5.000.000,- & 24 & $24 \%$ \\
\hline
\end{tabular}

Source: processed data, 2019. 
Table 2. Value of Importance Average (Yi) and Performance Average (Xi) in each attribute

\begin{tabular}{|c|c|c|c|}
\hline Attribute & Name of Attributes & $\begin{array}{l}\text { Importance } \\
\text { Average (Yi) }\end{array}$ & $\begin{array}{l}\text { Performance } \\
\text { Average (Xi) }\end{array}$ \\
\hline 1 & Security & 4.67 & 3.93 \\
\hline 2 & Availability of parking space & 4.53 & 3.83 \\
\hline 3 & $\begin{array}{l}\text { Availability of information and service centers in Sam Poo } \\
\text { Kong Temple area }\end{array}$ & 4.4 & 3.4 \\
\hline 4 & Cleanliness in Sam Poo Kong temple & 4.7 & 3.93 \\
\hline 5 & Cleanliness in the area around Sam Poo Kong Temple & 4.5 & 3.8 \\
\hline 6 & $\begin{array}{l}\text { Availability of information about activities in Sam Poo Kong } \\
\text { Temple through printed, electronic and social media }\end{array}$ & 4.23 & 3.37 \\
\hline 7 & Transportation (ease) facility & 4.13 & 3.77 \\
\hline 8 & Availability of restaurants around Sam Poo Kong Temple & 3.87 & 3.33 \\
\hline 9 & Toilet cleanliness & 4.13 & 3.83 \\
\hline 10 & $\begin{array}{l}\text { Availability of lodging accommodation near Sam Poo Kong } \\
\text { Temple }\end{array}$ & 3.43 & 3.13 \\
\hline 11 & Affordable entry tickets & 4.03 & 3.56 \\
\hline 12 & $\begin{array}{l}\text { Availability of complete unique souvenirs of Semarang and } \\
\text { Sam Poo Kong }\end{array}$ & 3.63 & 3.03 \\
\hline 13 & $\begin{array}{l}\text { Availability of special traditional food of Semarang Sam Poo } \\
\text { Kong temple }\end{array}$ & 3.56 & 3.43 \\
\hline 14 & $\begin{array}{l}\text { Art performance events related to local wisdom and } \\
\text { religious ceremonies }\end{array}$ & 3.86 & 3.46 \\
\hline 15 & The beauty of Sam Poo Kong Temple & 4.16 & 3.83 \\
\hline 16 & Quality of employee services & 4.03 & 3.37 \\
\hline 17 & Convenience & 4.1 & 3.9 \\
\hline 18 & Access to reach the location & 3.7 & 2.9 \\
\hline 19 & Information about Sam Poo Kong Temple via website & 3.8 & 3.1 \\
\hline 20 & Tour guides reliability & 3.7 & 3.33 \\
\hline 21 & $\begin{array}{l}\text { Availability of places to rest within Sam Poo Kong Temple } \\
\text { area }\end{array}$ & 3.67 & 3.4 \\
\hline 22 & ATM availability & 3.63 & 3.1 \\
\hline 23 & $\begin{array}{l}\text { Availability of snacks and beverage stores around Sam Poo } \\
\text { Kong }\end{array}$ & 3.8 & 3.43 \\
\hline
\end{tabular}

Source: processed data, 2019.

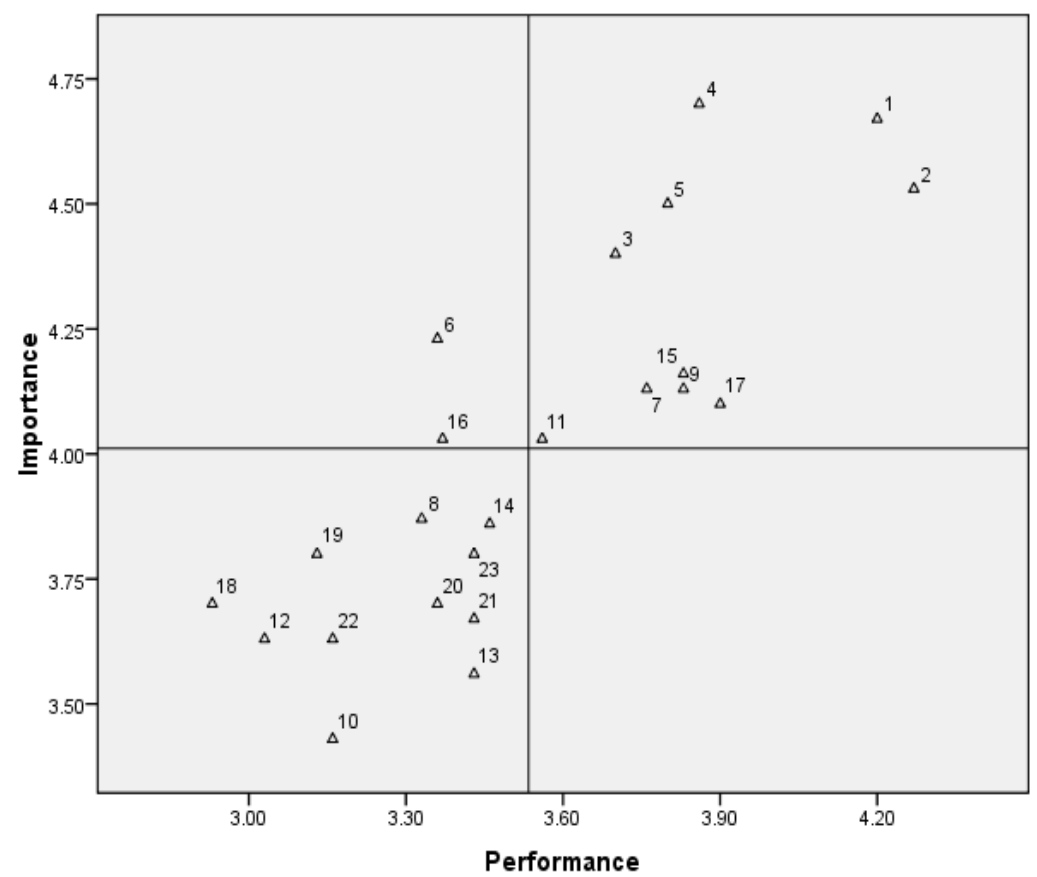

Figure 2. Importance-Performance Analysis (IPA) Graph of Sam Poo Kong 


\section{Quadrant I (Main priority)}

Quadrant I described that the performance of Sam Poo Kong Temple tourism attributes is low, while visitors' expectations are high. It shows that the attributes in quadrant I need to be prioritized to improve the performance. The attributes included in Quadrant I are the availability of information about activities in Sam Poo Kong Temple through printed, electronic, and social media (attribute 6) and the quality of employee services (attribute 16).

\section{Quadrant II (Maintain the good performance)}

Quadrant II shows that the performance attribute of Sam Poo Kong Temple tourism is high, and so is the level of visitor expectations is also high. It means the attributes in quadrant II must be maintained as all of these attributes make the product superior in visitors' opinion. The attributes included in quadrant II were security (attribute 1), availability of parking space (attribute 2), availability of information and service centers in Sam Poo Kong Temple area (attribute 3), cleanliness in Sam Poo Kong temple (attribute 4), cleanliness in the area around Sam Poo Kong Temple (attribute 5), transportation (ease) facility (attribute 7), toilet cleanliness (attribute 9), affordable entry tickets (attribute 11), the beauty of Sam Poo Kong Temple (attribute 15) and convenience (attribute 17).

\section{Quadrant III (Low priority)}

Quadrant III describes the low performance of Sam Poo Kong Temple tourism attributes, and the level of visitor expectations is also low. It shows that the attributes in quadrant III are not the top priority since the visitors' effect was small. These attributes included the availability of restaurants close to Sam Poo Kong temple (attribute 8), the availability of lodging close to Sam Poo Kong temple (attribute 10), the availability of complete unique souvenirs of Semarang and Sam Poo Kong (attribute 12), availability of special traditional food of Semarang Sam Poo Kong temple (attribute 13), (art) performance events related to local wisdom and religious ceremonies (attribute 14), (easy) access to locations (attribute 18), Sam Poo Kong temple information via web (attribute 19), reliability of tour guide (attribute 20 ), availability of places to rest (rest area) within Sam Poo Kong temple area (attribute 21), availability of ATM (attribute 22), and availability of snacks and beverage stores around Sam Poo Kong temple (attribute 23).

\section{Quadrant IV (Over performance)}

Quadrant IV describes the performance of Sam Poo Kong Temple tourism attributes as high but the level of visitor expectations is low. It shows that the tourism attributes considered by visitors as unimportant and felt to be too excessive. None of the attributes in this study was included in Quadrant IV.

\section{DISCUSSION}

Information about tourist attraction activities in Sam Poo Kong Temple through printed, electronic and social media (attribute 6)

According to respondents, the attribute of information about Sam Poo Kong Temple activities, through printed, electronic, and social media (attribute 6), was considered as the main important priority, and its performance needs to be improved. Information on Sam Poo Kong Temple activities through printed, electronic, and social media are the promotion forms that need to be conducted by the management of Sam Poo Kong Temple to increase the number of visitors.

Promotion is a crucial aspect of the marketing mix to spread the information, to influence or to persuade, and to remind the target markets of the companies (in this case, tourism object) and the services or products offered. Promotion is a communication part of marketing that provides information and knowledge in an informative and persuasive way to tourists [7]. There are various forms of promotion including advertisement (for instance: billboards, posters, brochures, audiovisual shows, etc.), sales promotions (such as gift sharing, price discounts, coupons), public relations, and publicity (e.g. press contacts, seminars), personal selling (such as trade shows), merchandising (for example souvenirs) and direct marketing (for instance: internet, catalogs).

The Quality of Employees' services (attribute 16)

As stated by respondents, an attribute of employees' service quality (attribute 16) was an attribute that was included in the highest priority and needed to be improved. Tourism human resource is an important factor in tourism development since tourism is an industry that is highly dependent on human existence as its driving factor. As an industry, human resources involved in tourism are those who are directly involved in tourism activities, i.e. managers of tourism business and workers/employees of tourism business. A highly skilled, competent, and professional workforce is an absolute necessity in global competition. 
The success of tourism activity is highly determined by the level of service quality provided to the tourists since the quality of service is considered to be directly proportional to the tourists' satisfaction. Hence, if tourists' satisfaction is fulfilled, it is expected that the appreciation in improving procedures of service will be better. Furthermore, if tourists feel satisfied with the quality of service of a tourism object, it will ultimately affect tourists' intention to revisit the tourism object [20].

The quality of service may include several aspects of competence, one of which is the human resources (HR) aspect. Human resource capabilities consist of skills, knowledge, and attitudes. When the skills, knowledge, and attitudes become the priorities for the improvement to be more professional. Hence, it will affect the implementation of the task, and if the task is carried out more professionally, it will result in better service quality. Based on the discussion above, the strategies to increase the attractiveness of Sam Poo Kong Temple are:

1. The management of Sam Poo Kong Temple can use all forms of promotion to introduce Sam Poo Kong Temple. However, the easiest and cheapest means of promotion today is by social media, i.e. Youtube, Facebook, Twitter, and Instagram, etc.

2. There are several ways to improve the quality of tourism human resources, especially for workers/employees of private tourism businesses, such as by conducting human resources training and development. Such training and development is an effort to reduce/eliminate the gap between the ability of employees and the need in the business world/tourism industry. The effort is carried out through the improvement of employees' competencies by increasing their knowledge and skills as well as changing their attitudes and/or behavior.

3. Maintaining the factors that are already considered good, such as security, availability of parking lots, ease of transportation, cleanliness, facilities, beauty, comfort, affordable entry tickets, and availability of information in the Sam Poo Kong environment.

\section{CONCLUSION}

This study concluded that the main priority (quadrant I) that must be improved by the management of Sam Poo Kong Temple is the attribute of information about activities in Sam
Poo Kong Temple through printed, electronic, and social media and employee service quality attribute. Some of the attributes which can be maintained in its performance (quadrant II) include security, availability of parking space, availability of information and service centers in Sam Poo Kong Temple area, cleanliness in Sam Poo Kong Temple, cleanliness in the area around Sam Poo Kong Temple, transportation facility, cleanliness of toilets in Sam Poo Kong, affordable entry tickets, the beauty of Sam Poo Kong Temple and visitors convenience in Sam Poo Kong temple tourism site.

In addition, attributes possessing low priority (quadrant III) included security, availability of parking space, availability of information and service centers in Sam Poo Kong Temple area, cleanliness in Sam Poo Kong Temple, cleanliness in the area around Sam Poo Kong Temple, transportation facility, cleanliness of toilets in Sam Poo Kong temple, affordable entry tickets, the beauty of Sam Poo Kong Temple and convenience. However, there is not any attribute possessing excessive-performance (quadrant IV).

The suggestion proposed in this research is to improve the performance of high priority attributes. The first suggestion is to carry out various promotion forms to increase the attractiveness of the Sam Poo Kong temple. One of the easiest and most inexpensive promotions is through social media (Facebook, Twitter, and Instagram). Second, improving the quality of human resources through formal and informal human resources training and development.

\section{REFERENCES}

[1] Sedarmayanti. 2014. Membangun dan mengembangkan kebudayaan dan industri pariwisata (bunga rampai tulisan pariwisata). PT. Refika Aditama. Bandung.

[2] Ratman, D. R. 2016. Development of priority tourism destinations 2016-2019. Ministry of Tourism, Republic of Indonesia. Jakarta.

[3] Hidayat, A. S. 2015. Persiapan sektor pariwisata indonesia dalam menghadapi masyarakat ekonomi ASEAN 2015. LIPI Press. Jakarta.

[4] Damanik, J. 2013. Pariwisata Indonesia: antara peluang dan tantangan. Pustaka Pelajar. Yogyakarta.

[5] Tourism and Culture Office of Semarang City. 2010. The Strategic Plan SKPD for 2010-2015. Tourism and Culture Office. Semarang. 
[6] Kotler, P., K. L. Keller, 2009. Manajemen pemasaran, $1^{\text {st }} E d$. Erlangga. Jakarta.

[7] Suryadana, M. L., V. Octavia. 2015. Pengantar pemasaran pariwisata. Penerbit Alfabeta. Bandung.

[8] Djeri, L., P. Stamenković, I. Blešić, S. Milićević, and M. Ivkov. 2018. An importance-performance analysis of destination competitiveness factors: case of Jablanica Distric in Serbia. Economic Research-Ekonomska Istrazivanja 31(1), 811 $-826$.

[9] Medina-Munoz, D. R., and R. D. MedinaMunoz, 2014. The attractiveness of wellness destinations: an importance-performance satisfaction approach. International Journal of Tourism Research 16, 521-533.

[10] Malcolm, C. D., and D. Ramsey. 2014. Specialization and importance-performance in visitors to a natural history museum: The Canadian Fossil Discovery Centre. European Journal of Tourism, Hospitality and Recreation 5(1), 9-34.

[11] Johann, Maria. 2014. The ImportancePerformance Analysis: An evaluation of tourist satisfaction with the destination attributes. International Journal of Economic Practices and Theories 4(5), 572578

[12] Timang, V. V. S., A. Antariksa, and I. R. D. Ari. 2014. Tourism development strategy of Buntula'bi Balusu Sub-Village, North Toraja regency based on tourist perception. Journal of Indonesian Tourism and Development Studies 2(3), 95-102.

[13] Farid, A., Soemarmo, Marsoedi, and B. Setiawan. 2013. Importance performance analysis of the marine tourism in Bawean Island Indonesia. British Journal of Marketing Studies 1(2), 33-41.

[14] Barbieri, C. 2010. An importanceperformance analysis of the motivation behind agritourism and other farm enterprise development in Canada. Journal of Rural and Community Development 5, 120.

[15] Chen, J., S. W. Stanis, C. Barbieri, S. Xu. 2010. An application of importanceperformance analysis to recreational storm chasing. Proceeding of the 2010 Northeastern Recreation Research Symposium.

[16] Martilla, J. A., and J. C. James, 1977. Importance Performance Analysis. Journal of Marketing, 77-79.
[17] Martinez, C. L. 2003. Evaluation report: tools cluster network. CenterPoint Institute, Inc, Arizona.

[18] Brandt, D. R. 2000. An outside-in approach to determining customer-driven priorities for improvement and innovation. White Paper Series, Vol. 5.

[19] Sita, N. 2017. Serba serbi sejarah Klenteng Sam Poo Kong di Semarang. Available at: https://www.goodnewsfromindonesia.id/20 $17 / 12 / 28 /$ serba-serbi-sejarah-klentengsam-poo-kong.

[20] Rukuižienè, R. 2014. Sustainable tourism development implications to local economy. Regional Formation and Development Studies 14(3), 170-177. DOI: 10.15181/rfds. v14i3.873. 